\title{
Biological activity exerted by omega-3 fatty acids on body mass index, glucose, total cholesterol and blood pressure in obese children
}

\author{
Elodia García-Cervera ${ }^{1}$, Lauro Figueroa-Valverde ${ }^{1 *}$, Eduardo Pool Gómez ${ }^{1}$, Marcela Rosas-Nexticapa ${ }^{2}$, Hau-Heredia Lenin ${ }^{2}$, Mateu- \\ Armand Virginia ${ }^{2}$, Parra-Galindo Perla ${ }^{2}$ and Cauich-Carrillo Regina ${ }^{1}$ \\ ${ }^{1}$ Laboratory of Pharmaco-Chemistry at the Faculty of Chemical Biological Sciences of the University Autonomous of Campeche, Av. Agustín Melgar s/n, Col \\ Buenavista C.P.24039 Campeche Cam., México \\ ${ }^{2}$ Facultad de Nutrición, Universidad Veracruzana. Médicos y Odontólogos s/n, 91010, Xalapa, Veracruz, México
}

\begin{abstract}
Background: Obesity is risk factor to development cardiovascular diseases. There are several studies which indicate that fatty acids can exert changes in body fat in children. However, the results found relatively are few and have generally been conducted over short time periods with small sample sizes, making it difficult to draw definitive conclusions.

Objective: In this study the effect induced by omega-3 fatty acids on some biological parameters such as glucose, total cholesterol and body mass index levels in obese children were evaluated.

Methods: A dietary intake of gummies with omega-3 fatty acids at dose (100-350 mg) was administered to obese children. Then, glucose, total cholesterol and body mass index levels were determinate using an apparatus (accutrend pluss) and enzyme-immunoassay techniques.

Results: The results showed that dietary intake of gummies with omega-3 fatty acids induces significantly changes on total cholesterol and body mass index levels in obese girls compared with obese boys.

Conclusions: All these data suggest that dietary intakes of omega-3 fatty acids could be used for the treatment of degree of obesity in obese girls. However, it is important to mention that it is also necessary to evaluate the beneficial effect of omega-3 fatty acids on other biological parameters involved in the degree of obesity as well as the possible toxicity involved in its administration.
\end{abstract}

\section{Introduction}

There are several studies which indicate that obesity is a factor risk involved in development of cardiovascular diseases [1-3]. This clinical pathology has been increasing during the last years during childhood and adolescence $[4,5]$. A report showed that in Union State American, the prevalence of obesity in children aged 6 to 11 years old has increased since the 60's [6]. Also in other regions such as Brazil [7] and Mexico [8] the prevalence of overweight in school-age children (511 years) has been increasing in recent years. This phenomenon could be caused by a bad diet and other risk factors; analyzing this hypothesis some nutritional alternatives has been used to control the degree of childhood obesity. For example, a study showed that an intake dietary of omega- 3 fatty acids can decrease the body mass index in children [9]. Other data suggest that the dietary intake of omega-3 fatty acids may be negatively related to obesity and modulate the metabolism of lipids, which could result in the loss of body mass index [10]. This premise is supported by some studies, which indicate that triglyceride concentrations are reduced by intake dietary of omega- 3 fatty acids at a dose of $3 \mathrm{~g}$ per day [11-13]. Also, some reports showed that an intake dietary of $4 \mathrm{~g}$ per day of omega-3 fatty acids can decrease the serum triglyceride concentrations [14,15]. However, other reports suggest that intake dietary of omega-3 fatty acids are associated with a higher prevalence of obesity [16]. All these data suggest that there is great controversy about the effect exerted by intake dietary of omega-3 fatty acids against obesity. Therefore, in this study the effect produced by omega-3 fatty acids on some factors associated with obesity such as glucose, body mass index, total cholesterol, and blood pressure levels was evaluated on obese children.

\section{Material and Methods}

Fifth and sixth graders $(\mathrm{n}=300)$ in two San Francisco de Campeche Mexico schools were invited to participate in a dietary intake gummy with omega- 3 fatty acids at dose of 100 to $350 \mathrm{mg}$. The parents were informed about the nature and the purpose of this study, and a consent form was signed by parents. In addition, the protocol of this research was previously approved by the ethical committee at the University Autonomous of Campeche.

Correspondence to: Lauro Figueroa-Valverde, Laboratory of PharmacoChemistry at the Faculty of Chemical Biological Sciences of the University Autonomous of Campeche, Av. Agustín Melgar s/n, Col Buenavista C.P.24039 Campeche Cam., México, E-mail: lauro_1999@yahoo.com

Received: January 31, 2018; Accepted: February 28, 2018; Published: March 05, 2018 


\section{Anthropometric measures}

Body mass index. Subjects were weighed without shoes. Standing height was measured without shoes to the nearest $0.5 \mathrm{~cm}$ with the use of a commercial stadiometer. Body mass index (BMI) was calculated by dividing weight $(\mathrm{kg})$ by height squared $\left(\mathrm{m}^{2}\right)$.

Blood Parameters Measured. A fasting blood sample was obtained for determination of glucose, triglyceride and total cholesterol concentrations were determined using Accutrend Pluss (Hoffmann-La Roche, Grenzach-Wyhlen, Germany) [19].

Evaluation of insulin levels. Insulin assay was performed by enzyme-immunoassay (Human Insulin ELISA kit, Sigma-Aldrich company) according to the manufacturer's instruction [20].

\section{Statistical analysis}

The obtained values are expressed as average \pm SE [21].

\section{Results}

\section{Evaluation of Body Mass Index}

Body Mass Index (BMI) differences in BMI levels for obese boys after of a dietary intake from gummies with omega- 3 fatty acids at a dose of $100 \mathrm{mg}\left(31.00 \pm 1.2 \mathrm{Kg} / \mathrm{m}^{2}\right), 150 \mathrm{mg}\left(30.04 \pm 1.2 \mathrm{Kg} / \mathrm{m}^{2}\right), 200$ $\mathrm{mg}\left(29.00 \pm 1.2 \mathrm{Kg} / \mathrm{m}^{2}\right), 210 \mathrm{mg}\left(29.29 \pm 1.2 \mathrm{Kg} / \mathrm{m}^{2}\right), 280(28.13 \pm 1.2$ $\left.\mathrm{Kg} / \mathrm{m}^{2}\right)$ and $350 \mathrm{mg}\left(25.00 \pm 1.7 \mathrm{Kg} / \mathrm{m}^{2}\right)$ in comparison with control $\left(31.48 \pm 1.7 \mathrm{Kg} / \mathrm{m}^{2}\right)$.

Other results indicate that an intake from gummies with omega-3 fatty acids in obese girls at different doses $100 \mathrm{mg}\left(29.00 \pm 1.2 \mathrm{Kg} / \mathrm{m}^{2}\right)$, $150 \mathrm{mg}\left(28.50 \pm 1.2 \mathrm{Kg} / \mathrm{m}^{2}\right), 200 \mathrm{mg}\left(28.00 \pm 1.2 \mathrm{Kg} / \mathrm{m}^{2}\right), 210 \mathrm{mg}(28.71$ $\left.\pm 1.2 \mathrm{Kg} / \mathrm{m}^{2}\right), 280\left(27.57 \pm 1.2 \mathrm{Kg} / \mathrm{m}^{2}\right)$ and $350 \mathrm{mg}\left(24.00 \pm 1.7 \mathrm{Kg} / \mathrm{m}^{2}\right)$ exert changes on BMI levels compared with control $\left(30.40 \pm 1.8 \mathrm{Kg} / \mathrm{m}^{2}\right)$.

\section{Determination of Glucose levels}

Administration of dietary intake from gummies with omega- 3 fatty acids to obese boys at dose of $100(102.00 \pm 1.7 \mathrm{dg} / \mathrm{ml}), 150(110.00$ $\pm 1.7 \mathrm{dg} / \mathrm{ml}), 200(115.02 \pm 1.7 \mathrm{dg} / \mathrm{ml}), 210 \mathrm{mg}(98.04 \pm 1.7 \mathrm{dg} / \mathrm{ml})$, $280 \mathrm{mg}(102.00 \pm 1.3 \mathrm{dg} / \mathrm{ml})$ and $350 \mathrm{mg}(108.00 \pm 1.4 \mathrm{dg} / \mathrm{ml})$ was no significant differences. Also, the dietary intake with omega-3 fatty acids in obese girls at dose of $100(98.00 \pm 1.6 \mathrm{dg} / \mathrm{ml}), 150(100.00 \pm 1.4 \mathrm{dg} /$ $\mathrm{ml}), 200(104.02 \pm 1.5 \mathrm{dg} / \mathrm{ml}), 210 \mathrm{mg}(110.00 \pm 1.6), 280 \mathrm{mg}(107.00$ $\pm 1.3)$ and $350 \mathrm{mg}(102.16 \pm 1.2)$ was no significantly changes in the glucose levels compared control conditions (100.02 \pm 1.6$)$.

\section{Evaluation of insulin levels}

The data found showed that insulin levels was not significantly difference in obese boys after of a dietary intake of gummies with omega-3 fatty acids at dose of $100(14.00 \pm 1.5 \mu \mathrm{U} / \mathrm{L}), 150(14.40 \pm$ $1.4 \mu \mathrm{U} / \mathrm{L}), 200(14.60 \pm 1.5 \mu \mathrm{U} / \mathrm{L}), 210 \mathrm{mg}(14.80 \pm 1.2 \mu \mathrm{U} / \mathrm{L}), 280$ $\mathrm{mg}(14.88 \pm 1.3 \mu \mathrm{U} / \mathrm{L})$ and $350 \mathrm{mg}(14.08 \pm 1.2 \mu \mathrm{U} / \mathrm{L})$ compared with conditions control $(14.0800 \pm 1.4 \mu \mathrm{U} / \mathrm{L})$. Additionally, other results showed that dietary intake of gummies with omega- 3 fatty acids in obese girls at doses of $100(14.50 \pm 1.4 \mu \mathrm{U} / \mathrm{L}), 150(14.88 \pm 1.3 \mu \mathrm{U} / \mathrm{L})$, $200(14.00 \pm 1.5 \mu \mathrm{U} / \mathrm{L}), 210 \mathrm{mg}(13.98 \pm 1.1 \mu \mathrm{U} / \mathrm{L}), 280 \mathrm{mg}(14.20 \pm$ $1.5 \mu \mathrm{U} / \mathrm{L})$ and $350 \mathrm{mg}(14.88 \pm 1.4 \mu \mathrm{U} / \mathrm{L})$ was no significant differences compared with control $(13.88 \pm 1.5 \mu \mathrm{U} / \mathrm{L})$.

\section{Cholesterol total}

The results showed significantly variations in cholesterol total levels for obese boys after of a dietary intake of gummies with omega- 3 fatty acids at dose of $100(202.00 \pm 1.6 \mathrm{mg} / \mathrm{dl}), 150(194 \pm 1.5 \mathrm{mg} / \mathrm{dl}), 200$
$(190.00 \pm 1.7 \mathrm{mg} / \mathrm{dl}), 210 \mathrm{mg}(188.14 \pm 1.6 \mathrm{mg} / \mathrm{dl}), 280 \mathrm{mg}(172.12 \pm$ $1.8 \mathrm{mg} / \mathrm{dl})$ and $350 \mathrm{mg}(152.10 \pm 1.9 \mathrm{mg} / \mathrm{dl})$ in comparison with obese boys without treatment. Other data showed in the Figure 2 indicated that dietary intake with omega-3 fatty acids in obese girls at dose of $100(186.00 \pm 1.6 \mathrm{mg} / \mathrm{dl}), 150(182.00 \pm 1.5 \mathrm{mg} / \mathrm{dl}), 200(180.00 \pm 1.7$ $\mathrm{mg} / \mathrm{dl}), 210 \mathrm{mg}(176.00 \pm 1.6 \mathrm{mg} / \mathrm{dl}), 280 \mathrm{mg}(170.00 \pm 1.6 \mathrm{mg} / \mathrm{dl})$ and $350 \mathrm{mg}(144.10 \pm 1.9 \mathrm{mg} / \mathrm{dl})$ exert changes on cholesterol total levels compared with conditions control $(188.75 \pm 1.5 \mathrm{mg} / \mathrm{dl})$.

\section{Blood pressure}

On the other hand, other results from a dietary intake of gummies with omega- 3 fatty acids in obese boys showed significant changes on blood pressure at dose of $100 \mathrm{mg}(114.00 \mathrm{mg} / \mathrm{dl} \pm 12.0), 150 \mathrm{mg}(108.00$ $\mathrm{mg} / \mathrm{dl} \pm 14.0), 200 \mathrm{mg}(116.00 \mathrm{mg} / \mathrm{dl} \pm 17.0) 210 \mathrm{mg}(114.20 \mathrm{mg} / \mathrm{dl}$ $\pm 15.0), 280 \mathrm{mg}(118.02 \mathrm{mg} / \mathrm{dl} \pm 13.0)$ and $350 \mathrm{mg}(110.200 \mathrm{mg} / \mathrm{dl} \pm$ $14.0)$ with relation to control $(116.00 \mathrm{mg} / \mathrm{dl} \pm 13.0)$. Finally, other data showed that dietary intake with omega- 3 fatty acids in obese girls at dose of $100(106.00 \pm 1.4 \mathrm{mg} / \mathrm{dl}), 150(104.00 \pm 1.4 \mathrm{mg} / \mathrm{dl}), 200(102.00$ $\pm 1.7 \mathrm{mg} / \mathrm{dl}), 210 \mathrm{mg}(99.00 \pm 1.4 \mathrm{mg} / \mathrm{dl}), 280 \mathrm{mg}(102.00 \pm 1.5 \mathrm{mg} / \mathrm{dl})$ and $350 \mathrm{mg}(102.04 \pm 1.6 \mathrm{mg} / \mathrm{dl})$ produce changes on blood pressure compared with conditions control $(112.02 \pm 1.4 \mathrm{mg} / \mathrm{dl})$.

\section{Discussion}

There are some reports which indicate that obesity is a factor risks to development several cardiovascular diseases $[2,3]$. To reduce this clinical pathology some strategies have been used; for example, an intake dietary with high-fiber [22], fruit and vegetable [23] or use of drugs such as Orlistat, sibutiramine, rimonabant and others; however, some of these treatment may produce some adverse effects [24].

\section{Evaluation of effect produced by omega- 3 fatty acids on Body Mass Index (BMI)}

In the search of some therapeutic alternative to reduce the obesity, the effect exerted by a dietary intake of gummies with omega- 3 fatty acids on some parameters clinical such as body mass index glucose, cholesterol and blood pressure in an obese children population was evaluated. The results showed that effect produced by a dietary intake of gummies with omega-3 fatty acids decreased BMI levels in obese girls compared to obese boys and control (obese girls without treatment) at different doses (Figure 1); these data are supported by some studies previously reported [25], which indicate that administration of omega- 3 fatty acids decreased the BMI in obese girls.

\section{Determination of biological activity exerted by omega-3 fatty acids on Cholesterol total concentration}

Analyzing the data above mentioned and other studies which suggest that intake diet of $n-3$ polyunsaturated fatty acids can produce changes on total cholesterol levels [26], in this study, the effect exerted by omega- 3 fatty acids on total cholesterol concentration in obese children was evaluated. The results found indicated that omega- 3 fatty acids significantly reduce the total cholesterol concentration in obese girls compared with obese boys and controls (Figure 2). However, it is noteworthy that some studies indicate that omega- 3 fatty acids, in addition of alterations of total cholesterol also may exert changes in blood pressure levels [27].

\section{Evaluation of effect produced by omega-3 fatty acids on Blood Pressure}

In this study, the biological activity of by dietary intake of gummies with omega-3 fatty acids on blood pressure in obese children was 


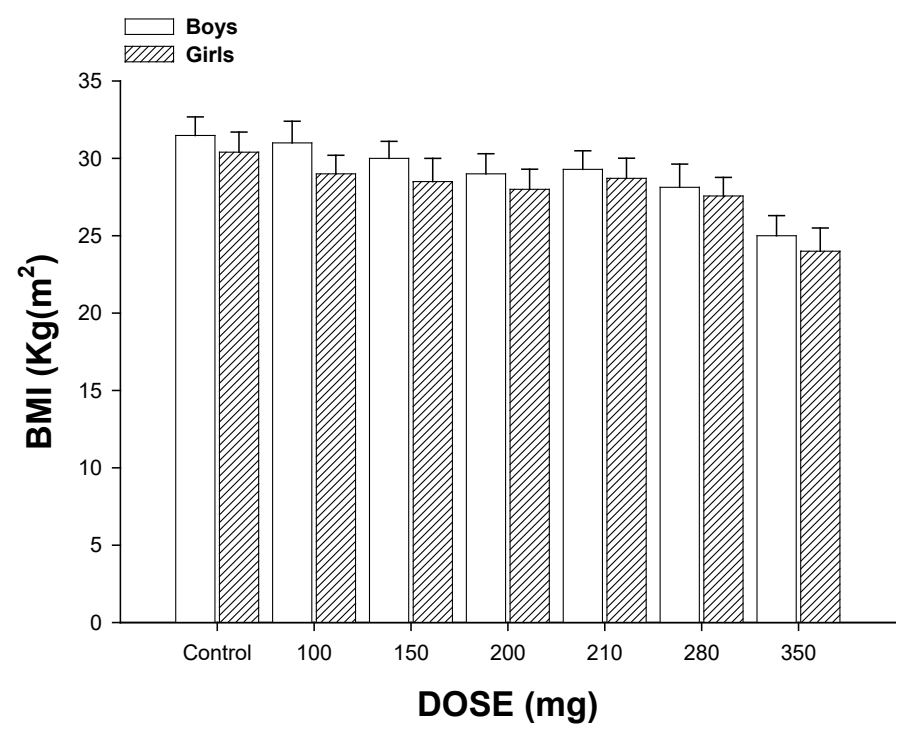

Figure 1. Effects exerted by omega-3 fatty acids at dose of $100-350 \mathrm{mg}$ on body mass index (BMI) levels. The results shown that omega- 3 fatty acids exert changes on BMI in a dose-dependent manner; however, this phenomenon was significantly different $(\boldsymbol{p}=0.05)$ in obese girls compared with obese boys. The effects are expressed as mean \pm S.E.

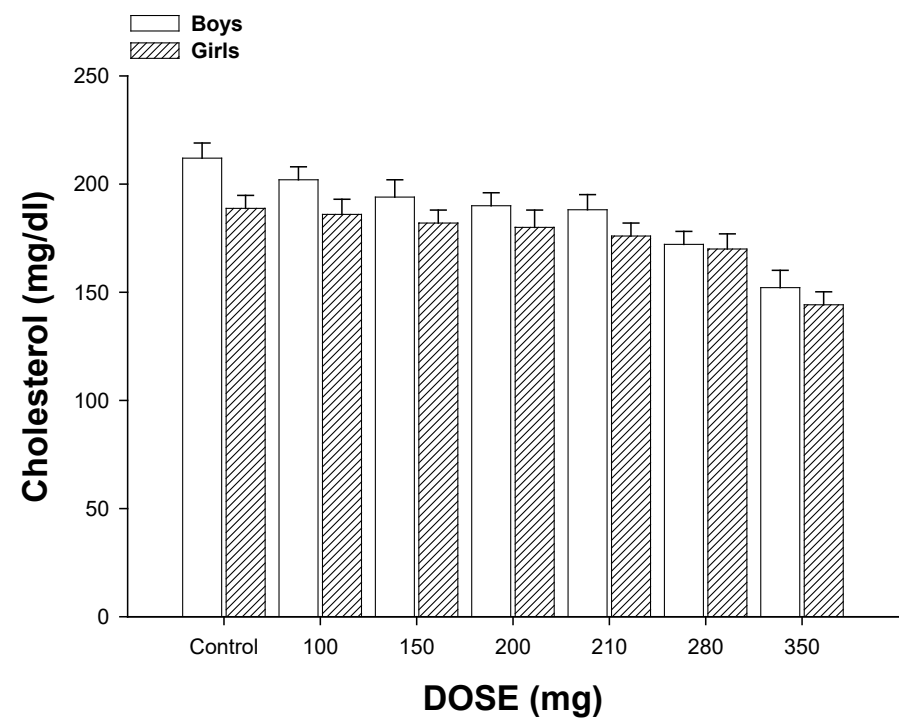

Figure 2. Biological activity induced by omega-3 fatty acids at dose of $100-350 \mathrm{mg}$ on total cholesterol levels. The results showed that omega-3 fatty acids exert changes on total cholesterol concentration in a dose-dependent manner; however this phenomenon was significantly different $(\boldsymbol{p}=0.05)$ in obese girls compared with obese boys. The effects are expressed as mean \pm S.E.

evaluated. The results showed (Figure 3 ) that omega-3 fatty acids decreased the blood pressure in a dependent-dose manner compared with obese boys and controls (obese children, without treatment). These data are similar to other studies that indicate that omega- 3 fatty acids can induce changes in blood pressure in hypertensive patients [28]. It is important to mention that this phenomenon also may also be conditioned by changes of glucose levels such happening with biological activity induced by other substance in obese patients [29].

\section{Determination of biological activity exerted by omega-3 fatty acids on glucose levels}

Some studies indicate that intake diet of omega- 3 polyunsaturated fatty acids can increase glucose levels obese and diabetic patients [30]; however, other studies indicate that omega-3 fatty acids improve glucose metabolism without have effects on obesity degree in women [31]. Therefore, in this study, the biological activity exerted by an intake diet of omega-3 polyunsaturated fatty acids on glucose levels was evaluated in obese children. The results showed (Figure 4) that intake diet of omega-3 polyunsaturated fatty acids no exerted significantly differences on glucose levels in both obese boys and girls. This phenomenon is possibly a result of the methodology and the different doses used or the complex correlation between diet and other lifestyle factors.

\section{Evaluation of effect exerted by omega- 3 fatty acids on insulin concentration}

Some reports suggest that omega- 3 fatty acids may induce changes on insulin levels. Analyzing this premise, in this study the effect of a dietary intake omega- 3 fatty acids was evaluated in obese children. The results showed that the administration of different doses of gummies

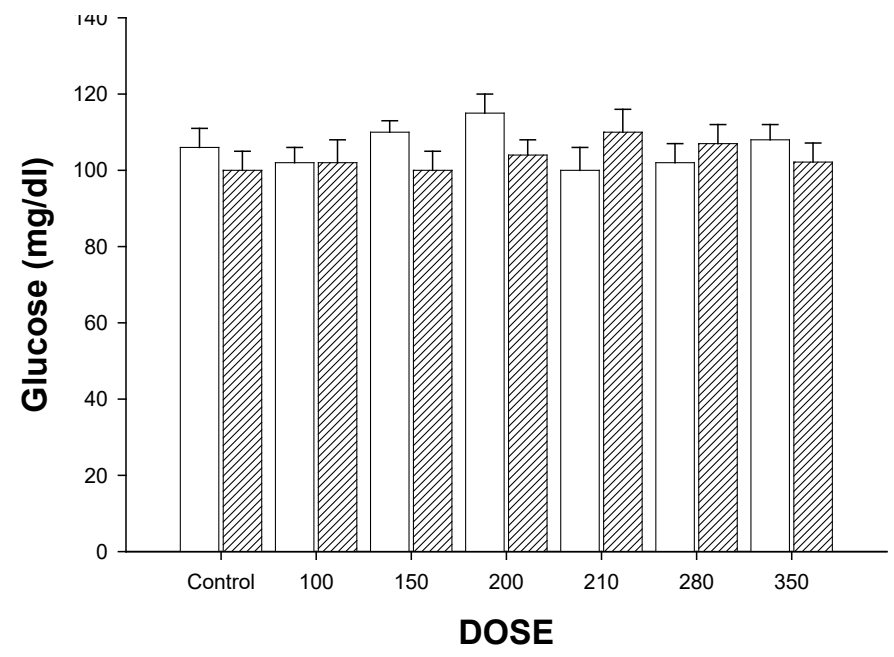

Figure 3. Biological activity induced by omega- 3 fatty acids at dose of 100-350 mg on blood pressure levels. The results showed that omega- 3 fatty acids induce changes blood pressure in a dose-dependent manner; however this phenomenon was significantly different ( $\boldsymbol{p}=$ 0.05 ) in obese girls compared with obese boys. The effects are expressed as mean \pm S.E.

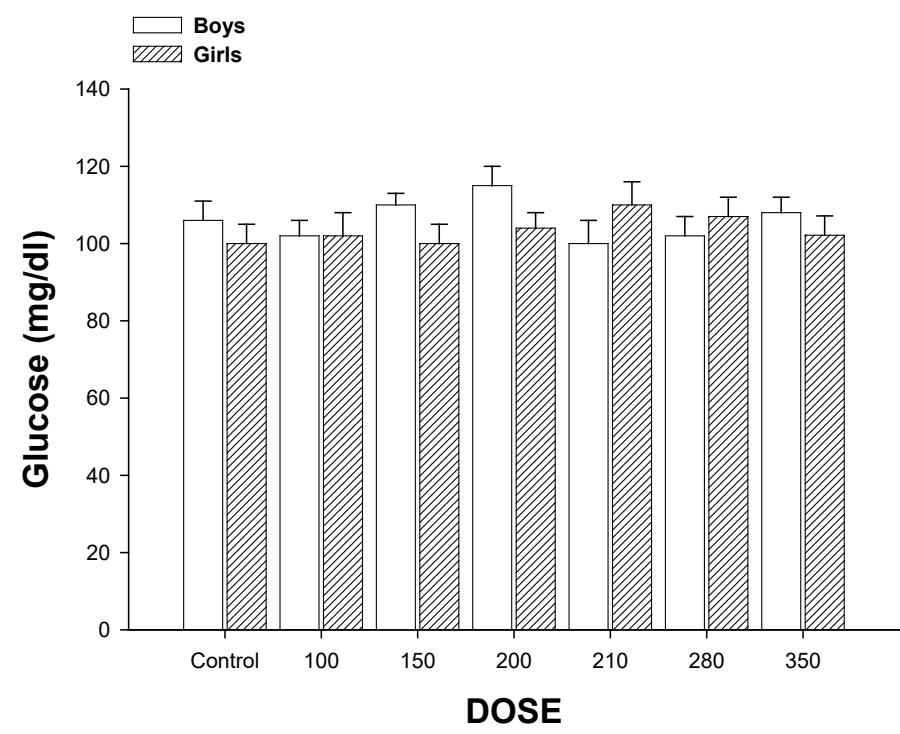

Figure 4. Biological activity produced by omega-3 fatty acids at dose of 100-350 $\mathrm{mg}$ on glucose levels. The results showed that omega- 3 fatty acids do not exert changes on glucose levels in obese children. The effects are expressed as mean \pm S.E. 


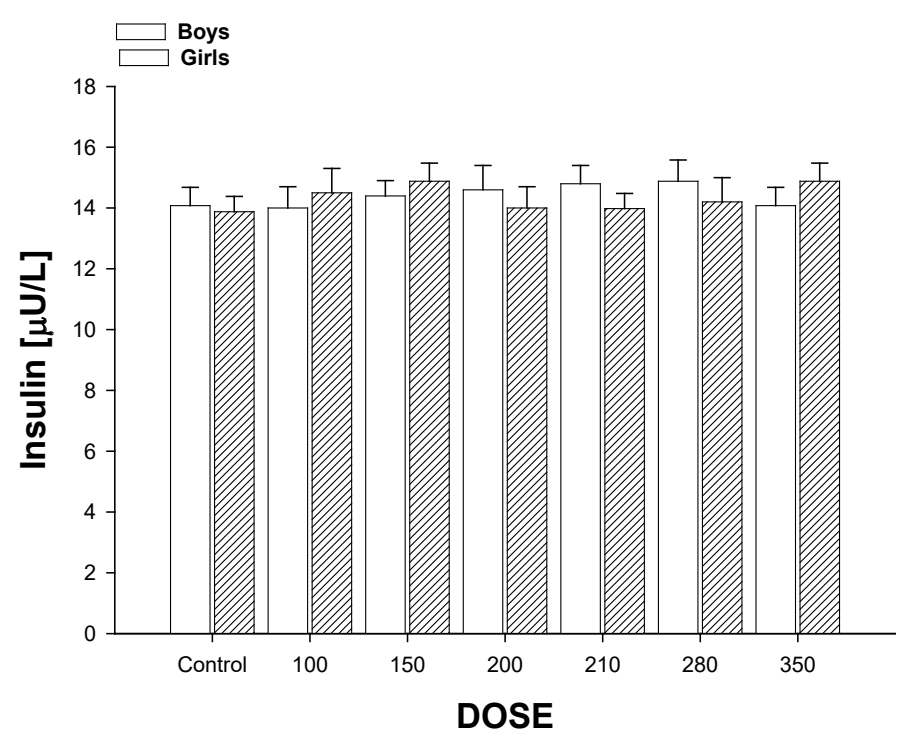

Figure 5. Effect exerted by omega-3 fatty acids at dose of 100-350 $\mathrm{mg}$ on insulin concentration. The results showed that omega- 3 fatty acids do not exert changes on insulin levels in obese children. The effects are expressed as mean \pm S.E

with omega-3 fatty acids no exert significantly changes in insulin concentration in both boys and girls; this data indicated that omega-3 fatty acids no exert activity on synthesis or release of insulin (Figure 5). These data are contrary to other reports which indicate that an intake dietary of omega 3 fatty acids enhancing insulin secretion.

\section{Conclusions}

Intake diet of omega-3 polyunsaturated fatty acids exerts effect against body mass index and cholesterol in a dose-dependent manner. However, it is important to mention that there is a possibility that high doses could increase this phenomenon.

\section{Author Contributions}

All the authors contributed to evaluation of effect exerted by omega-3 polyunsaturated fatty acids and data analysis of final manuscript.

\section{References}

1. Cohn J, Archibald D, Ziesche S, Franciosa J, Harston W, et al. (1986) Effect of vasodilator therapy on mortality in chronic congestive heart failure. Results of a Veterans Administration Cooperative Study. New Eng J Med 314: 1547-1552. [Crossref]

2. Sowers JR (1998) Obesity and cardiovascular disease. Clin Chem 44: 1821-1825. [Crossref]

3. Pérez Pérez A, Ybarra Muñoz J, Blay Cortés V, de Pablos Velasco P (2007) Obesity and cardiovascular disease. Public Health Nutr 10: 1156-1163. [Crossref]

4. Lyznicki JM, Young DC, Riggs JA, Davis RM; Council on Scientific Affairs, American Medical Association (2001) Obesity: assessment and management in primary care. $\mathrm{Am}$ Fam Physician 63: 2185-2196. [Crossref]

5. Chavarria S (2002) Definicion y criterios de obesidad. Nutr Clin 5: 236-240.

6. Hedley AA, Ogden CL, Johnson CL, Carroll MD, Curtin LR, et al. (2004) Prevalence of overweight and obesity among US children, adolescents, and adults, 1999-2002. JAMA 291: 2847-2850. [Crossref]

7. de Assis MA, Rolland-Cachera MF, Grosseman S, de Vasconcelos FA, Luna ME, et al. (2005) Obesity, overweight and thinness in schoolchildren of the city of Florianópolis, Southern Brazil. Eur J Clin Nutr 59: 1015-1021. [Crossref]

8. Hernandez B, Cuevas-Nasu L, Shamah-Levy T, Monterrubio EA, Ramírez-Silva CI, et al. (2003) Factors associated with overweight in Mexican school-age children: results from the National Nutrition Survey 1999. Salud Publica Mex 45: S551- S557. [Crossref]

9. López-Alarcón M, Martínez-Coronado A, Velarde-Castro O, Rendón-Macías E, Fernández J (2011) Supplementation of n3 long-chain polyunsaturated fatty acid synergistically decreases insulin resistance with weight loss of obese prepubertal and pubertal children. Arch Med Res 42: 502-508. [Crossref]
10. Micallef M, Munro I, Phang M, Garg M (2009) Plasma n-3 Polyunsaturated Fatty Acids are negatively associated with obesity. Br J Nutr 102: 1370-1374. [Crossref]

11. McKenney JM, Sica D (2007) Role of prescription omega-3 fatty acids in the treatment of hypertriglyceridemia. Pharmacotherapy 27: 715-728. [Crossref]

12. Skulas-Ray A, West S, Davidson M, Kris-Etherton P (2008) Omega-3 fatty acid concentrates in the treatment of moderate hypertriglyceridemia. Expert Opin Pharmacother 9: 1237-1248. [Crossref]

13. Davidson MH (2006) Mechanisms for the hypotriglyceridemic effect of marine omega-3 fatty acids. Am J Cardiol 98: 27i-33i. [Crossref]

14. Harris WS (1997) n-3 fatty acids and serum lipoproteins: human studies. Am J Clin Nutr 65: 1645S-1654S. [Crossref]

15. Woodman R, Mori T, Burke V, Puddey I, Watts G, et al. (2002) Effects of purified eicosapentaenoic and docosahexaenoic acids on glycemic control, blood pressure, and serum lipids in type 2 diabetic patients with treated hypertension. Am J Clin Nutr 76:1007-1015. [Crossref]

16. Iso H, Rexrode KM, Stampfer MJ, Manson JE, Colditz GA, et al. (2001) Intake of fish and omega-3 fatty acids and risk of stroke in women. JAMA 285: 304-312. [Crossref]

17. Gottschling H, Reuter W, Ronquist G, Steinmetz A, Hattemer A (1995) Multicentre evaluation of a non-wipe system for the rapid determination of total cholesterol in capillary blood, Accutrend Cholesterol on Accutrend GC. Eur J Clin Chem Clin Biochem 33: 373-381. [Crossref]

18. Chien L, Accili D, Tall A (2004) Increased CD36 protein as a response to defective insulin signaling in macrophages. J Clin Invest 113:764-773. [Crossref]

19. Liu S, Willett W, Manson J, Hu F, Rosner B, et al. (2003) Relation between changes in intakes of dietary fiber and grain products and changes in weight and development of obesity among middle-aged women. Am J Clin Nutr 78: 5 920-927. [Crossref]

20. Epstein LH, Gordy CC, Raynor HA, Beddome M, Kilanowski CK, et al. (2001) Increasing fruit and vegetable intake and decreasing fat and sugar intake in families at risk for childhood obesity. Obes Res 9: 171-178. [Crossref]

21. Padwal RS, Majumdar SR (2007) Drug treatments for obesity: orlistat, sibutramine, and rimonabant. Lancet 369: 71-77. [Crossref]

22. García-Cervera E, Figueroa-Valverde L, Pool GómezE, Díaz-Cedillo F, RosasNexticapa M (2015) Effect of omega-3 fatty acids on triglycerides and BMI levels in obese children. Curr Pediatr Res 19: 1-8.

23. Simopoulos AP (2002) The importance of the ratio of omega-6/omega-3 essential fatty acids. Biomed Pharmacother 56: 365-379. [Crossref]

24. Lungershausen YK, Abbey M, Nestel PJ, Howe PR (1994) Reduction of blood pressure and plasma triglycerides by omega-3 fatty acids in treated hypertensives. $J$ Hypertens 12: 1041-1045. [Crossref]

25. Oh SY, Ryue J, Hsieh CH, Bell DE (1991) Eggs enriched in omega-3 fatty acids and alterations in lipid concentrations in plasma and lipoproteins and in blood pressure. $\mathrm{Am}$ J Clin Nutr 54: 689-695. [Crossref]

26. Kestin M, Clifton P, Belling G, Nestel P (1990) n-3 fatty acids of marine origin lower systolic blood pressure and triglycerides but raise LDL cholesterol compared with n-3 and n-6 fatty acids from plants. Am J Clin Nutr 51: 1028-1034. [Crossref]

27. Friday K, Childs M, Tsunehara C, Fujimoto W, Bierman E, et al. (1989) Elevated Plasma Glucose and Lowered Triglyceride Levels From Omega-3 Fatty Acid Supplementation in Type II Diabetes. Diabetes Care 12: 276-281. [Crossref]

28. Rafraf M, Mohammadi E, Asghari M, Farzadi L (2012) Omega-3 fatty acids improve glucose metabolism without effects on obesity values and serum visfatin levels in women with polycystic ovary syndrome. J Am Coll Nutr 31: 361- 368. [Crossref]

29. Popp-Snijders C, Schouten J, Heine R, Meer J, Veen E (1987) Dietary supplementation of omega-3 polyunsaturated fatty acids improves insulin sensitivity in non-insulindependent diabetes. Diabetes Res 4: 141-147. [Crossref]

30. Lardinois CK (1987) The role of omega 3 fatty acids on insulin secretion and insulin sensitivity. Med Hypotheses 24: 243-248. [Crossref]

31. Baur L, O'Connor J, Pan D, Storlien L (1999) Relationships between maternal risk of insulin resistance and the child's muscle membrane fatty acid composition. Diabetes 48: 112-116. [Crossref]

Copyright: (C2018 García-Cervera E. This is an open-access article distributed under the terms of the Creative Commons Attribution License, which permits unrestricted use, distribution, and reproduction in any medium, provided the original author and source are credited. 